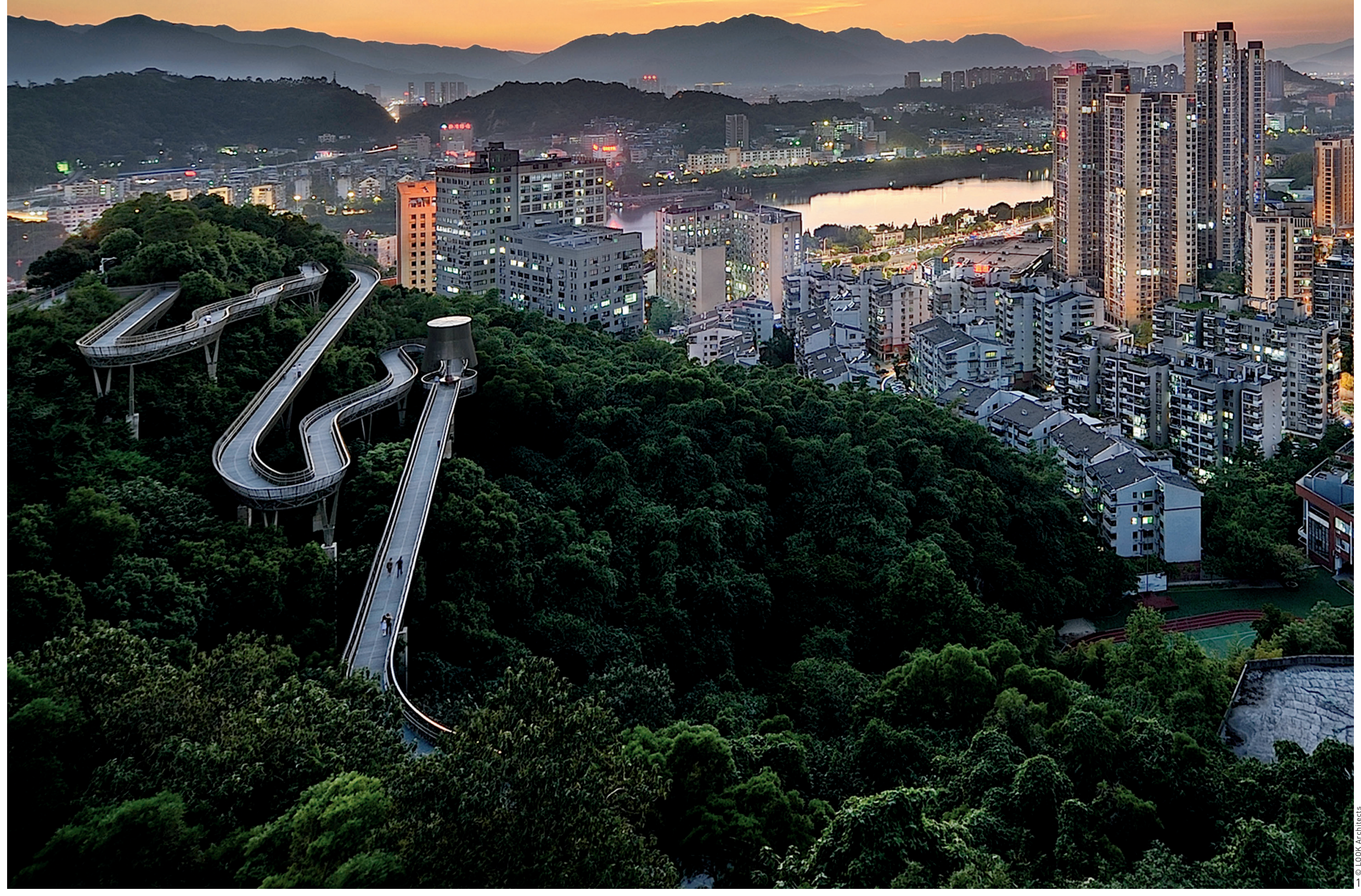




\section{福州“福道”森林步行道设计 DESIGN OF THE FUDAO FOREST WALKWAY IN FUZHOU}

新加坡锐科建筑设计咨询有限公司，奧雅纳工程顾问有限公司新加坡分公司 / LOOK Architects*', Arup Singapore

*18 Boon Lay Way, \#09-135 TradeHub 21, Singapore 609966 office@lookarchitects.com
有关此项目的更多信息 请访问:

http://www. works/urban-design. html $\overline{\mathrm{https}}$ ://www.arup.com/ projects/fudao
1. “福道” 森林步行道的 一部分依山而建, 俯瞰 着福州城区。

Portion of the fores walk sits at the cliff overseeing the cityscape.

\section{景观和公共福祉}

随着人口不断增长和老城区整体迁移 的持续推进，城市可持续发展的相关问题正 不断引发公众及城市管理者的关注。如何兼 顾经济增长与自然环境保护, 并使社区居民 真正从中受益, 从而营造充满活力的城市生 活, 是当前景观设计从业者面临的重大挑战 之一。在此背景下, “景观” 被赋予了新的 含义。正如芝加哥大学英语和艺术史教授威 廉 . 约翰 · 托马斯 . 米切尔在其著作《风景 与权力》中所述: “景观是人与自然、自我 与他人之间交流的媒介。从这种意义上看, 它就像货币, 本身没有多少价值, 却可以作 为无数种潜在价值的载体。”[1]景观不仅仅是 一种可感可见的实物, 还是一种展现文化力 量的手段, 以及创造文化认同感和社会认同 感的重要工具。这一媒介特性使“景观”为 认识并干预城市问题提供了一种新视角。

以景观为媒介的干预手段必须平衡开发 与保护的关系。这不仅对保障生态系统、城 市和公众的福祉至为关键, 也有助于经济的 稳健增长。位于中国福建省福州市金牛山公 园自然保护区、绵延19km的空中步道系统即 是一个典型案例, 充分证明了景观的确是一 种可承载无限价值的 “载体”。

福州市的人口逾750万, 是福建省的省
会，其名称的字面含义是 “有福之州”，并 曾是中国绿地率最高的城市之一；2015年, 福州位列布鲁金斯学会 “全球增长最快的都 市区”第10位，经济的加速发展导致其城市 边界不断扩张, 侵占了周边宜人的自然景观。

\section{“有福之道”}

金牛山是福州市区面积最大的山地, 因 其独特的地形与区位条件, 过去被用作军营 驻扎地与殡葬用地, 公众基本上很难进入。 因此, 山区的生态环境尚未受到明显的人为干 扰, 成为了福州难能可贵的 “城市绿肺”。

2017年, 一条长6.3km的高架森林步道 在金牛山落成, 成为长达 $19 \mathrm{~km}$ 、连结金牛山 与闽江下游的跨城装置 “福道” (1) (寓意“有 福之道” ) 的一部分。通过这一项目, 金牛 山周边的墓地被重新整合并统一修建逝者纪 念堂, 其自然资源得以向公众开放, 整个地 区也因此被注入活力。

福道的设计注重环境的敏感性和空间的 尺度感, 并充分利用现有场地的自然地形, 最大限度地减少施工可能对周围环境带来的 影响。蜿蜒起伏的步道沿线共有10个入口 与城区相接, 将金牛山转化为活跃的城市枢 纽; 沿途串联起众多的休想场所、观景台、 瞭望塔、茶室以及 $3 \mathrm{hm}^{2}$ 的未来商业中心等核心
摘要

快速的城镇化进程虽然促使全球大城市的经济显著增长, 但也一直在无情地吞险对于生态系统和环境健康至关重要的绿 地和农田。这种失衡的发展已对所有生命的共同福祉造成了极 大威胁, 因此, 当代景观设计学尘须考虑生态、美学与经济的 协调发展，以积极应对这一挑战。位于中国福州的“福道” 林步行道即是将设计美学与工程效率相结合的范例之一。作为 中国首条钢结构空中步道系统，其成功地将一座曾经的荒山变 成了公众健身走廊, 以对环境的最小干扰和创新的设计方法赢 得了国际关注。

关键词

最小干扰; 共同福祉; 森林步道; 模块化系统; 轻型结构; 生态保护

\section{ABSTRACT}

While rapid spread of urbanization brings dramatical economic growth to major cities worldwide, they are relentlessly eating up green spaces and farmlands essential to the ecosystem and environmental health, risking the common benefits for all lives with inbalanced development and putting a burden on contemporary Landscape Architecture to coordinate ecology and aesthetic with economy. By integrating design aesthetic and engineering efficiency, Fudao, a first-of-its-kind aesthelic and engineering efficiency, Fudao, a first-or ils-kind this che this chatlenge successfully by opening up a once desolated mountain area to the public with a minimum environmental disturbance achieved by an innovative design approach, which gains international attention.

KEY WORDS

Minimum Intervention; Common Benefit; Forest Walkway; Modular System; Lightweight Structure; Ecology Protection

\section{整理 王胤瑜}

译 黄延峰

EDITED BY WANG Yinyu

TRANSLATED BY HUANG Yanfeng 


\begin{tabular}{|c|}
\hline 项目地址： \\
\hline 中国福建省福州市 \\
\hline 项目面积: \\
\hline $760000 \mathrm{~m}^{2}$ \\
\hline 项目委托： \\
\hline 福州市鼓楼区人民政府 \\
\hline 项目团队： \\
\hline 新加坡锐科建筑设计咨询有限公司 (建筑设计与城市设 \\
\hline \multirow{4}{*}{$\begin{array}{l}\text { 计）；奧雅纳工程顾问公司新加坡分公司（结构工程设 } \\
\text { 计）；福州市规划设计研究院（建筑设计协助、结构工程设 } \\
\text { 计协助、机械与电气工程协助、定量测绘与景观设计）； } \\
\text { 东省基础工程集团有限公司、中国第一治金建设有限责任公 } \\
\text { 司 (建造施工） }\end{array}$} \\
\hline \\
\hline \\
\hline \\
\hline \multirow{2}{*}{$\begin{array}{l}\text { 设计时间: } \\
\text { 2014 2016年 }\end{array}$} \\
\hline \\
\hline 建造时间： \\
\hline \multirow{2}{*}{$\begin{array}{l}\text { 2016 2018年 } \\
\text { 所获奖项: }\end{array}$} \\
\hline \\
\hline 2018年新加坡总统设计奖 “年度设计” \\
\hline 2018年亚洲最具影响力设计大奖 \\
\hline 2018年芝加哥雅典娜博物馆建筑与设计奖 \\
\hline LOCATION: \\
\hline Fuzhou, Fujian Province, China \\
\hline AREA (SIZE): \\
\hline $760,000 \mathrm{~m}^{2}$ \\
\hline CLIENT: \\
\hline People's Government of Gulou District, Fuzhou \\
\hline PROJECT TEAM: \\
\hline \multirow{2}{*}{$\begin{array}{l}\text { LOOK Architects Pte Ltd (Architect and Urban Designer); } \\
\text { Arup Singapore Pte. Ltd. (Structural Design Engineer); }\end{array}$} \\
\hline \\
\hline Fuzhou Planning Design and Research Institute \\
\hline (Associated Architect, Local Structural Engineer, \\
\hline Mechanical \& Electrical Engineer, Quantity Surveyor, and \\
\hline Landscape Architect); Guangdong Foundation Engineering \\
\hline \multirow{2}{*}{$\begin{array}{l}\text { Group Co., Ltd., China First Metallurgical Group Co., Ltd. } \\
\text { (Main Contractor) }\end{array}$} \\
\hline \\
\hline DESIGN PERIOD: \\
\hline $2014 \sim 2016$ \\
\hline CONSTRUCTION TIME: \\
\hline $2016 \sim 2018$ \\
\hline AWARDS: \\
\hline "Design of the Year" at the Singapore's President's Design \\
\hline Award 2018 \\
\hline "Grand Award" at Design for Asia Awards 2018 \\
\hline Chicago Athenaeum Museum of Architecture and Design \\
\hline Award in 2018 \\
\hline
\end{tabular}

元素, 以倡导健康的城市生活方式, 使人们 能与原本难以靠近的自然景观亲密接触。

\section{严格限定下的设计与工程创新}

由于福道的设计理念是 “以人为本, 保护自然”, 为了使设计更加灵活地适应各 种不同的复杂地形，故其主体采用了创新的 装配部件式结构, 共包含5种按特定尺寸预 制的基本部件模块, 既便于运输和在施工现 场附近组装, 又可与周边的地形自然融合。 为应对起伏地形给施工、结构、安全和环境 带来的挑战, 设计团队研发了一种精确的模 块施工系统, 其可以将设计的模块有序地相 互连接, 并根据需要灵活调整安装方式, 以 避开重要树木的生长路径; 部分模块的地板 设有洞口, 可使树木从中穿过。为了进一步 减轻环境影响并简化组装, 部件间采用螺栓 连接, 最大限度地减少了现场焊接, 同时节 约了施工成本和时间, 提高了结构效率。设 计采用的轻型结构使模块的最大跨距可达 $14.4 \mathrm{~m}$, 且单个模块的重量被控制在一定范 围内, 以减少重型起重设备的使用, 进一步 降低了现场的施工痕迹和对山区原有生态的 干扰。

步道使用轻型钢格栅作为铺面材料, 以 便阳光和雨水都能够渗透下去, 使得底层的 植被能良好生长。其设计亦有意减少了横向 共振, 以提升步行的舒适度。步道由一系列
通过隐藏式螺母和螺栓组装的 $Y$ 型柱支撑, 其从树权的形态汲取灵感, 可与周围的森林 形成呼应; 这种轻巧、简洁的柱体设计也是 基于对工程效率与步行加速度影响的综合考 虑, 不仅效果美观, 也降低了工程造价。

新加坡总统设计奖评审团如此评价福道 的设计: “轻型钢材隐没在苍翠繁茂的背景 中, 让周围的自然景观成为主角。富有韵律 的钢结构布置形态轻盈, 设计的通用性则确 保了它可以尽可能满足所有访客的需求。” 这座蜿蜒的空中步道创造了一个全新的诗意 视野, 将福州这座城市鲜为人知的另一面展 现在公众眼前。其在严格的设计原则框架下 提出了卓越的创意和创新性工程设计, 以此 造福公众, 并实现了功能设计和工程效率的 完美结合, 对中国的城市公共景观设计具有 里程碑式的意义。

\section{福道的末来}

自2016年底开放以来，福道平均每天接 待约两万名游客。在2018年春节期间, 仅前 三天就有累计 19.4 万人来此游览。这座需要 1.5 小时走完全程的森林步道正在成为福州市 民和外地游客最喜爱的观光目的地之一。

福道的建设是福州市在创造经济和社会 价值的同时实现自然资源和现有生态保护的 一次成功尝试。创新的步道系统与优雅且高 效的结构解决方案, 将城市社区与郁郁䓤葱
2. 福道的 10 个入口之一。 穿过这些入口，游人便 从繁华的城区步入了宇 静的自然山林。

3. 设计将步行道与多种公 共设施及商业场所相结 合, 以鼓励步行活动。

2. One of the 10 entrances to the forest walk, transporting visitors from the bustling city to the tranquil natural to the tranquil natura environment.

3. Various public and commercial amenities are integrated with the design to assist pedestrians.
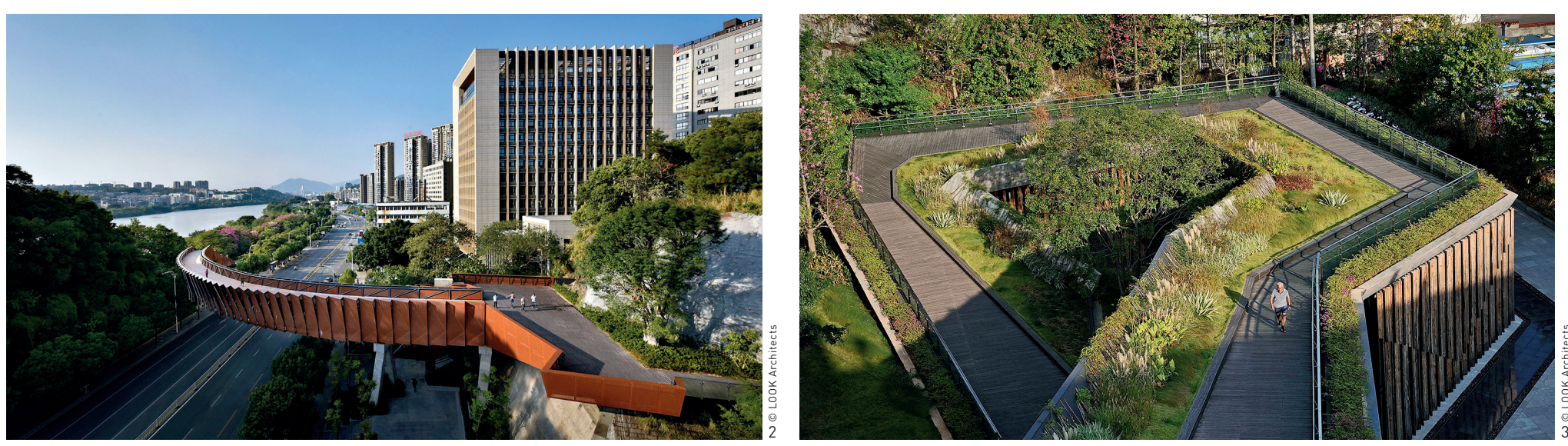


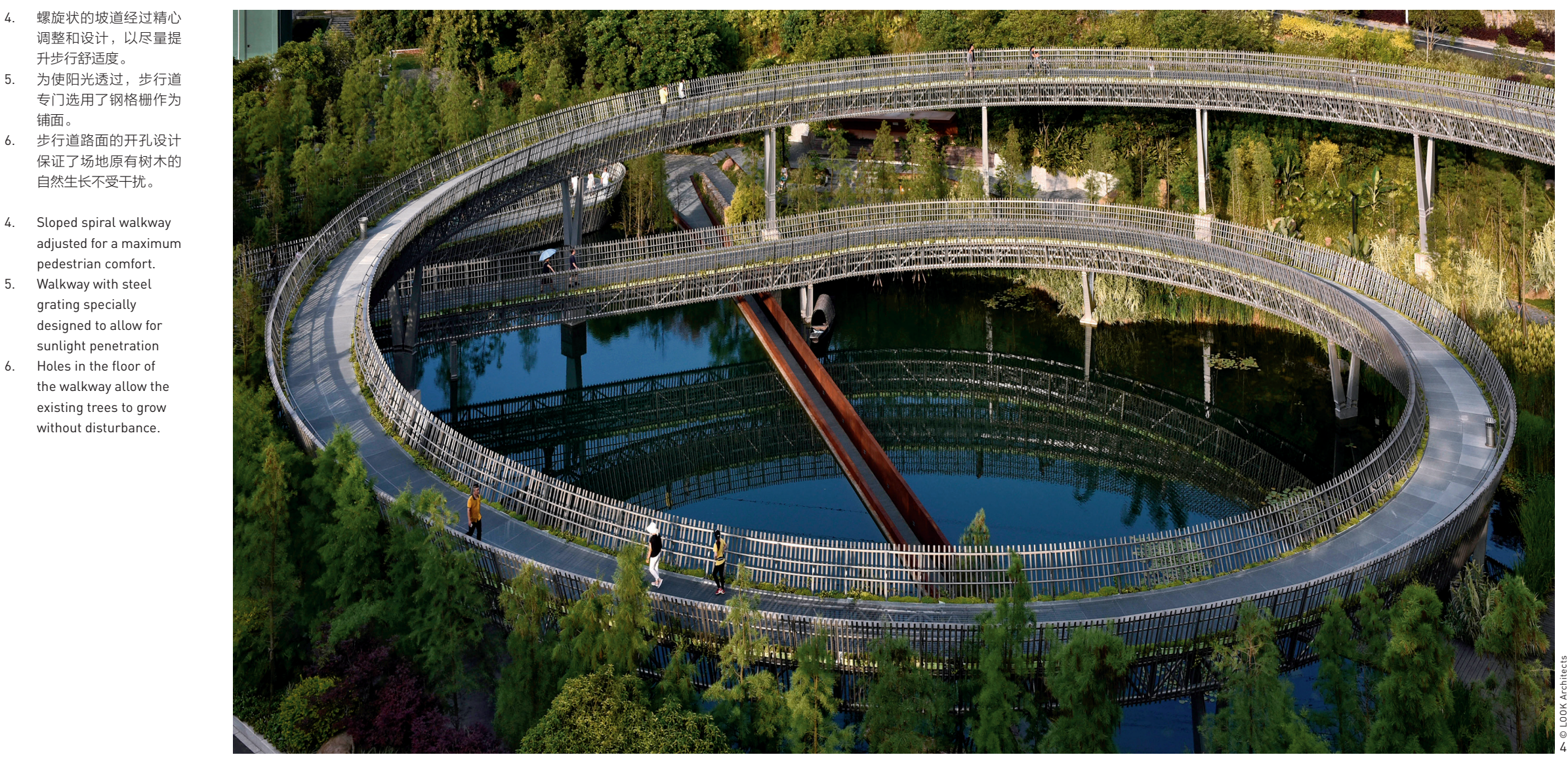

的自然景观连接起来, 使得金牛山这座曾经 神秘的“绿肺”焕发新生, 成为一个公众可 以自由进出的城市枢纽和国际知名的森林漫 步区, 不但促进了周边区域的经济转型, 也 提高了居民的生活质量。

作为一座开创性的城市森林步道, 福道 为公众提供了与郊野林地近距离接触的丰富 体验, 亦成为一处生机勃勃、引人流连的景 观和重要的城市文化象征, 构成一个城市形 象必不可少的一部分, 为城市生活和公众精 神注入了活力。LAF

致谢

本文图片由新加坡锐科建筑设计咨询有限公司与奥雅纳工程顾问公 司新加坡分公司提供；文字部分由奥雅纳工程顾问公司的陆洁露整 理，蒋麦瑞提供技术支持。在此一并表示诚挚感谢。
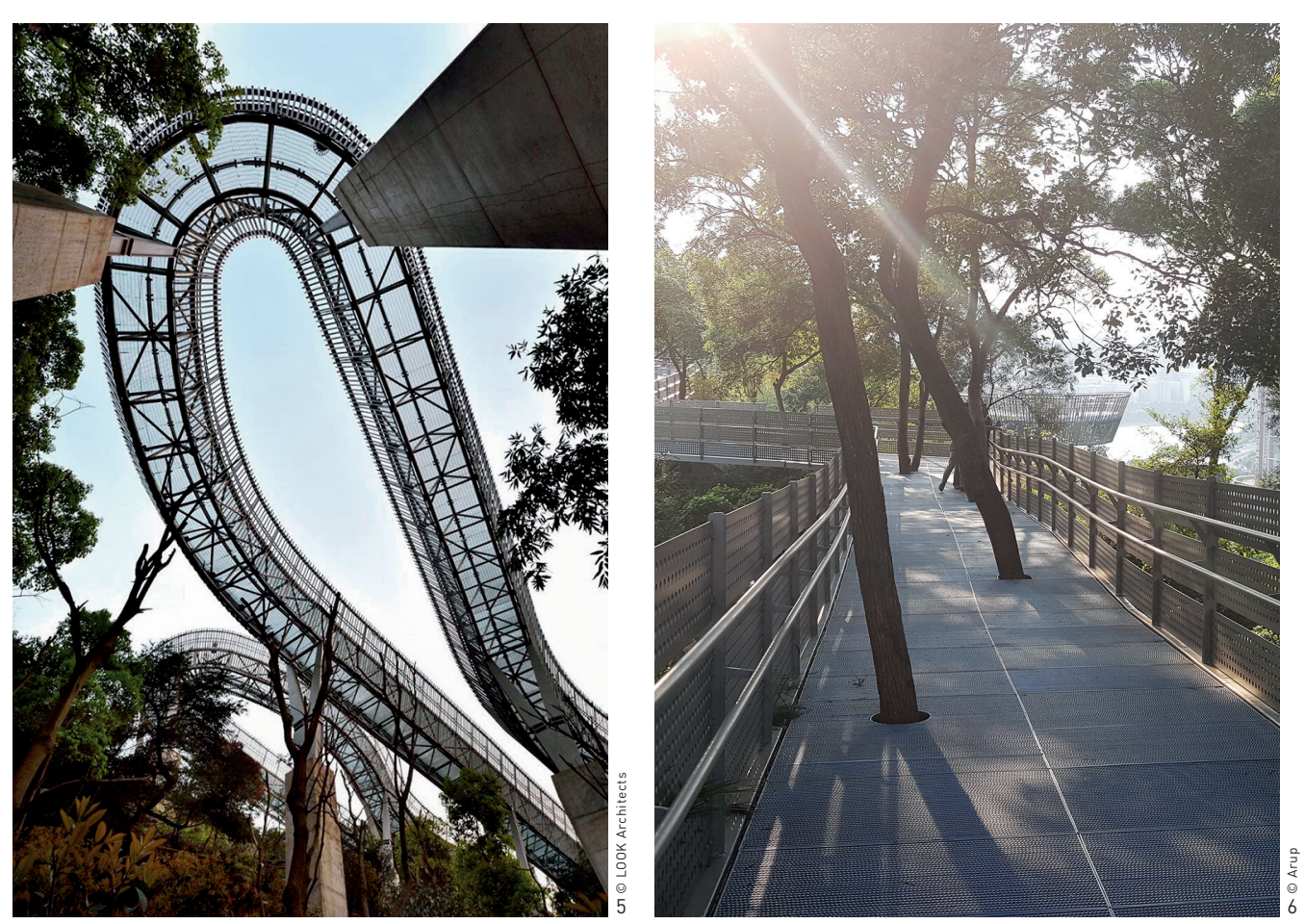


\section{Landscape and the Public Good}

With the constant population growth and aggregated inner-city migration, increasing concerns for sustainable urban development have been raised among the public and city officials.

One of the most significant challenges Landscape Architecture professionals are facing is how to offer a vibrant city life achieving both economic growth and natural environment protection as well as giving communities with all kinds of benefits, for which a new interpretation of landscape is demanded. In Landscape and Power, William John Thomas Mitchell, a distinguished professor of English and Art History at the University of Chicago, points out that "landscape is a medium of exchange between the human and the natural, the self and the other. As such, it is like money: good for nothing in itself, but expressive of a potential limitless reserve of value," ${ }^{[1]}$ suggesting that landscape is not simply an object to be seen, but also an instrument of cultural force, a central tool in the creation of cultural and social identity. This concept makes it possible to understand and intervene the existing urban problems with the new medium of landscape.

A balance between preservation and development of landscape intervention is not only essential to the well-being of the ecosystem, the city, and the public, but also a bustling opportunity for a vigorous economic growth. A 19-km-stretch elevated pedestrian network across the Jinniushan Park by the heart of Fuzhou City, Fujian Province, China, provided a paradigm that attests the "limitless reserve of value" in landscape.

As the capital of Fujian Province, Fuzhou has a population of a little over 7.5 million, the literal translation of whose name means "a city with blessing." It was among cities with most green spaces in
China. In 2015, Fuzhou was ranked the world's 10th fastest growing metropolitan area by Brookings Institution. An accelerating economic development drives Fuzhou to expand beyond its original boundary, encroaching upon its beloved surrounding natural landscape.

\section{A Walkway of Blessing}

The Jinniushan Mount is the largest mountain in Fuzhou. It was occupied with military camps and surrounded by burial grounds due to its unique topography and location, distancing itself from the public. Therefore, the natural environment of the mountain remains almost undisturbed, earning a reputation as the Green Lung of the city.

In 2017, a 6.3-km elevated forest walkway was built up in Jinniushan Mount, and formed part of the "Fudao" Ring ${ }^{(1)}$, a wider 19-km-long trans-urban connector, stretching to the northeast of Minjiang River. It is named Fudao, meaning "the Walkway of Blessing." Fudao is commissioned to revitalize the Jinniushan area by reconsolidating the burial sites, setting up a memorial hall for the lost souls and opening up the city's largest green lung to the public.

The design of Fudao is sensitive and intimate. It responses to the natural terrain of the existing site while minimizing construction footprint. The undulated walkway with 10 different entrances transforms a natural impediment into a vibrant urban hub. Incorporating numerous rest shelters, viewing decks, observation towers, teahouses, and an approximately $3 \mathrm{hm}^{2}$ future commercial hub in this 19-kilometer stretch, the design encourages wellness of city life and brings its visitors to a close proximity to natural environment in an otherwise unattainable part of city.

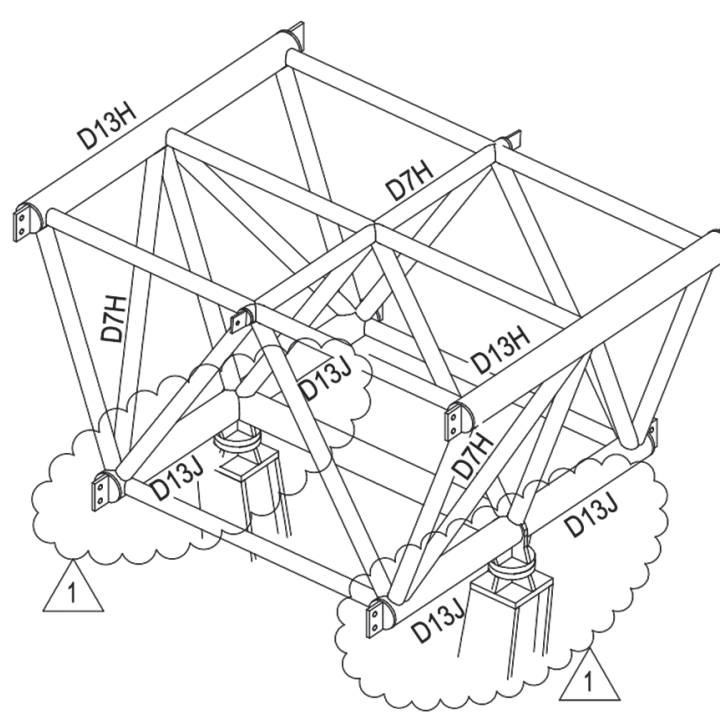

Module L1 Isometric 平坮模块 $L 1$ 等角

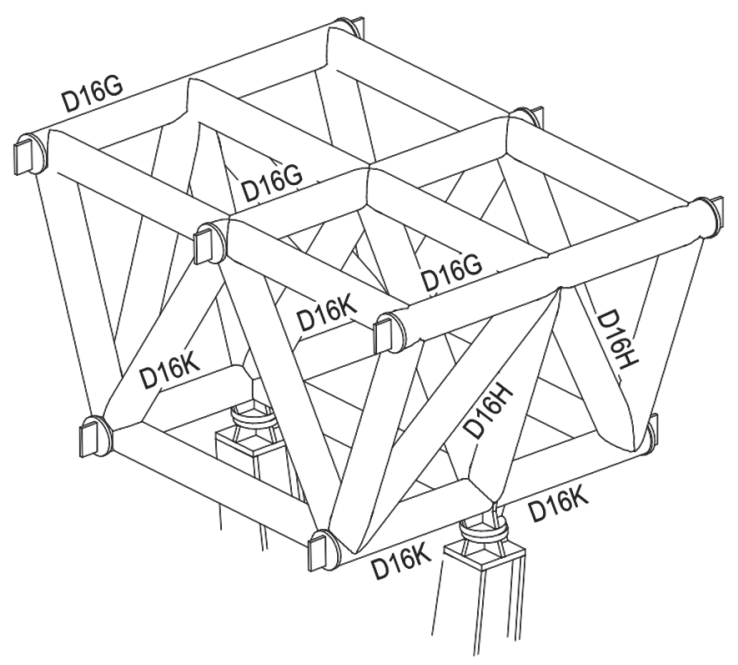

Module L1A Isometric

平坮模块L1A等角
For more information about this project, please visit: https://www. lookarchitects.com/en/ works/urban-design. html html ht//www.arup.com/ projects/fudao 
7. 步行道平坮模块 $\mathrm{L} 1 、$

L1A等角视图

步行道平坮模块 L $2 、 L 3$

平面及等角视图

7. Isometric views of

Module L1 and L1A of

the walkway

8. Plans and isometric

views of Module L2 and

L3 of the walkway

\section{Innovative Design and Engineering with Disciplined Construction}

Envisioned as a gateway to nature and an adaptation to the natural terrain, the architect proposed an innovative kit-of-part design of 5 basic prefabricated modules for easy transportation and assembly around the site, evoking a sense of natural terrain. Design engineers then developed a precise construction modular system to encounter the construction, structural, safety, and environmental challenges brought by this undulating terrain. The 5 types of modules could be systematically connected and dynamically adjusted to the configurations required to protect trees. Floors of some modules were holed to allow for trees to go through. To further mitigate impacts on the environment, bolted connections were designed for easy assembly to minimize onsite welding, reducing construction cost and time, and increasing structure efficiency. The lightweight structure, with a maximum span of 14.4 meters, helps control the weight of each module so as to reduce the need for heavy lifting equipment onsite, further minimizing construction footprint within the landscape and interference to the mountain ecology.

Besides, light-weight steel grating

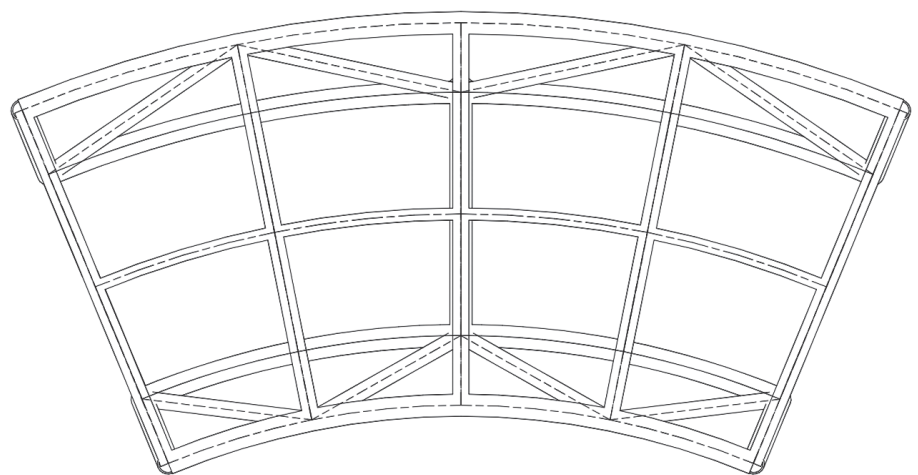

Module L2 Plan 平坮模块 $L 2$ 平面

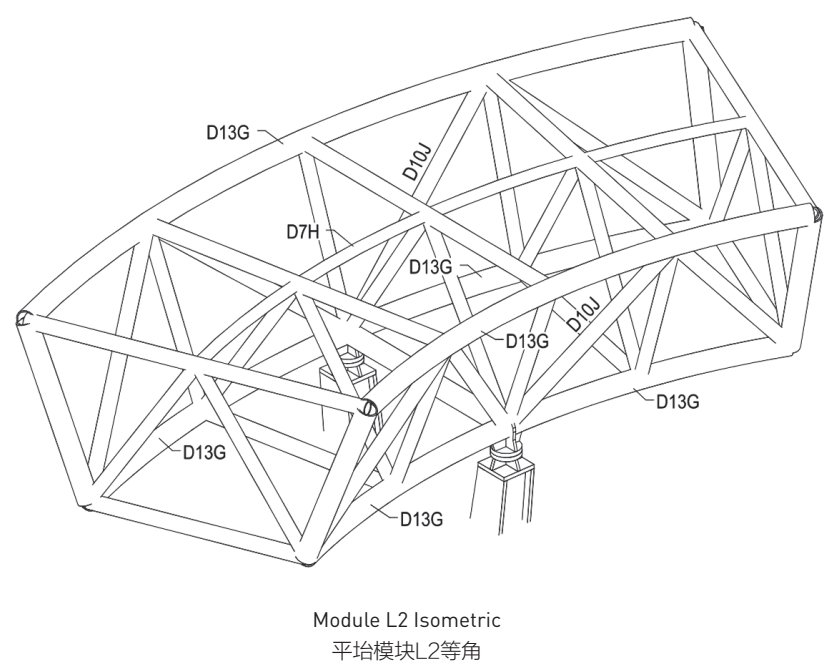

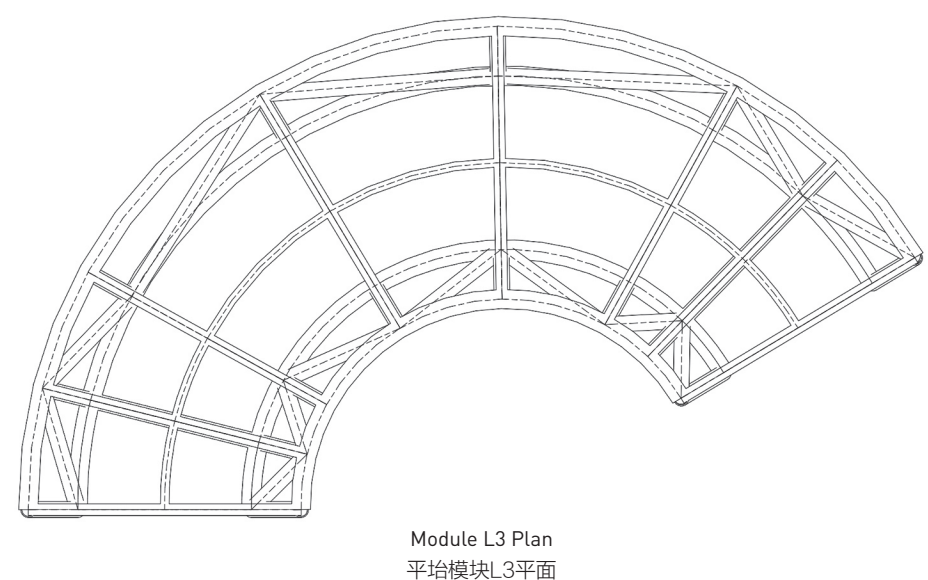

平坮模块 $\mathrm{L} 3$ 平面

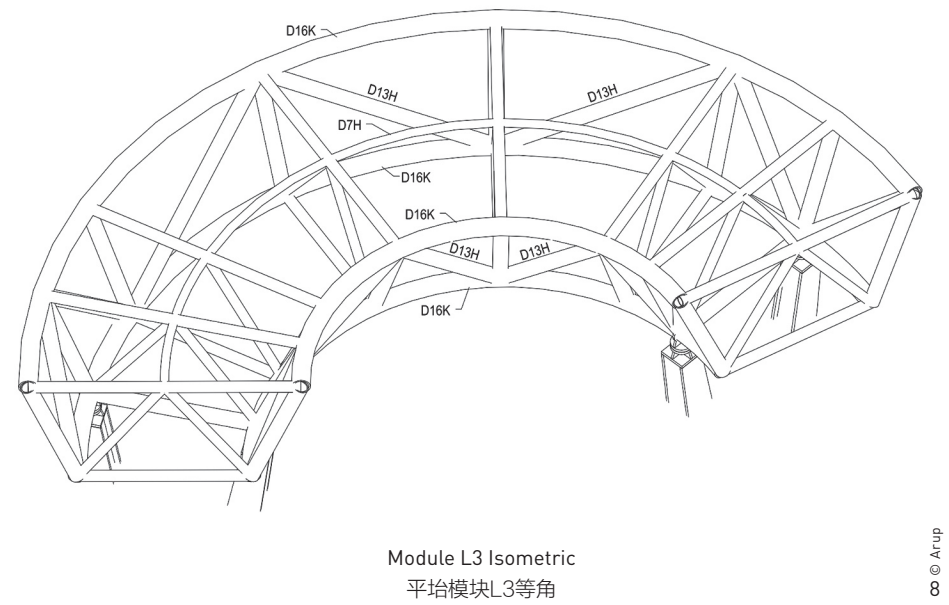



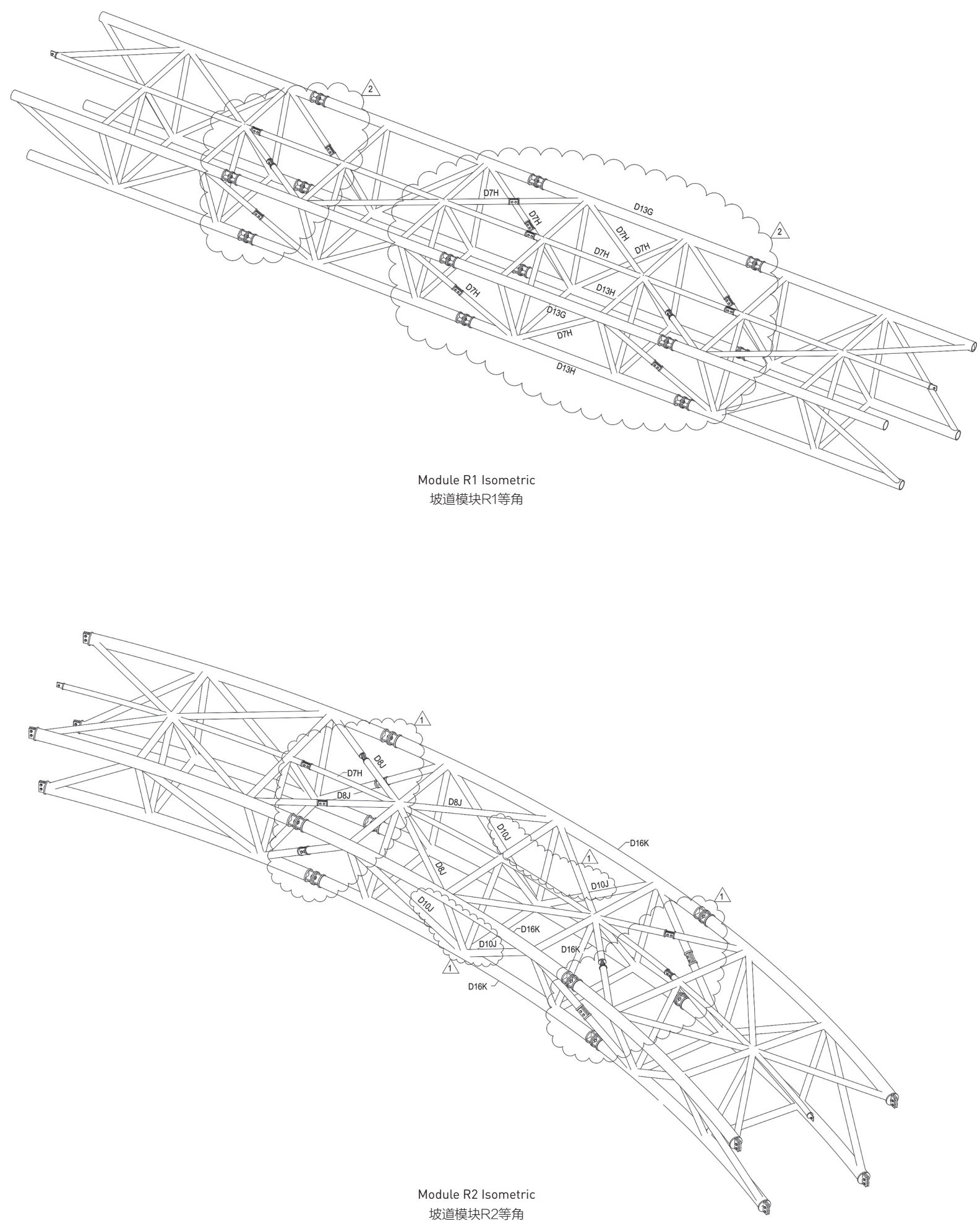

was specifically selected for floors and balustrades to admit sufficient sunlight and rainwater to the underlying vegetation, facilitating their growth. It manages to avoid lateral synchronous vibration that would bring discomfort to pedestrians. A series of $Y$-shaped columns with hidden nuts and bolts are elegantly designed in ranges to resemble branches of trees, blending in naturally with the surroundings. The columns are efficiently engineered and checked with the footfall acceleration on the walkway rather than limiting to the natural frequency, avoiding bulky elements to achieve aesthetics and reduce cost.

As the jury of Singapore's President's Design Award has commented, "the lightweight steel elements retreat into the lush background and allow the surrounding nature to take the central stage. There is a sense of lightness created by the rhythmic placement of the steel elements on the walkway. Universal design features ensure inclusiveness for everyone." This winding skywalk poetically opens up views towards the city in perspectives from which many would have never seen before. With the help from local contractors and consultants who follow through the design disciplines rigorously, this project marks an important milestone in China's urban public landscape design, as an excellence in design intent and innovative engineering for the public good. It is a combination of inclusive design and engineering efficiency immersing seamlessly into its natural environment.

\section{Future of Fudao}

Since its first opening in the end of 2016, Fudao has recorded with a 20,000 average visitors daily. At the beginning of 2018, an accumulated 194,000 visitors walked through the "walkway of blessing" 


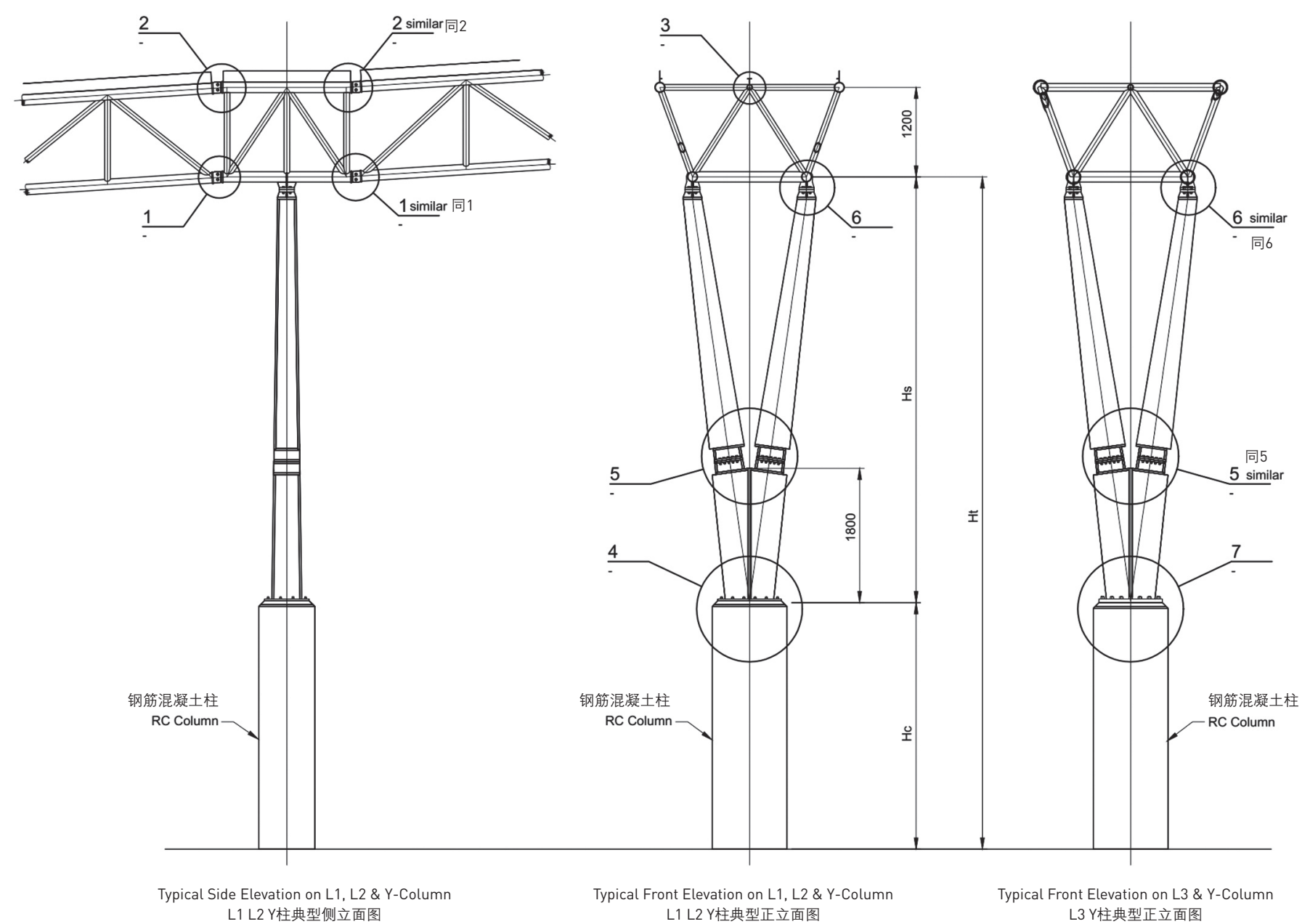
$\mathrm{R} 2$ 等角视图

10. $Y$ 型柱与三种平坮模块 连接关系的典型立面

9. Isometric views of Module R1 and R2 of the walkway

Three typical

sections of junction

of Y-Colu mith with during the first three days of Chinese Lunar New Year. The 1.5-hour forest walkway is becoming one of the most popular destinations for both locals and tourists.

The commission of Fudao is the city's successful attempt to conserve its natural resource and existing ecology while creating economic and social values. The innovative pedestrian network with an elegant and efficient structure solution revitalized the once mystified green lung to a public-accessible hub. The inviting green image elevated the status of Jinniushan area, once a desolated mountain, to an internationally well-known forest walkway, enabling an economic transformation around and raising the quality of life by connecting the urban community to the region's lush natural landscape.

While providing an enriched experience for the public to access the once indigenous hinterland, Fudao, as the first-of-its-kind urban forest walkway, is a thriving landscape and significant cultural signifier that is an essential part of the city image, bringing renewal and vigor to city life and public spirit with a mesmerizing journey awaiting the community. LAF

\section{ACKNOWLEDGEMENTS}

Images in this article are from LOOK Architects and Arup Singapore. Text is provided by LU Jielu with technical information supported by Mak Swee Chiang, both from Arup. We sincerely thank them for all these efforts.

\section{REFERENCE}

[1] Mitchell, W. J. T. (Ed.). (2002). Landscaped and Power (2nd ed). Chicago: University of Chicago Press. Retrieved from https://www. press.uchicago.edu/ucp/books/book/chicago/L/ bo3626791.html 